\title{
SPESIFIKASI SIMBOL KARTOGRAFIS PADA PETA TAKTUAL UNTUK KAUM TUNA NETRA
}

\author{
${ }^{1}$ Noorhadi Rahardjo, ${ }^{2}$ Su Rito Hardoyo \\ 1, 2 Jurusan Sains Informasi Geografi dan Pengembangan Wilayah, Fakultas Geografi UGM Yogyakarta. \\ Email: noorhadi ugm@yahoo.com dan surito@ugm.ac.id
}

\begin{abstract}
ABSTRAK
Tunanetra memerlukan sarana perolehan informasi yang dapat diterjemahkan dengan rabaan atau diperkuat dengan pendengaran, termasuk kebutuhan akan informasi kebumian dan atau lingkungan. Cara perolehan informasi seperti tersebut, kaum tunanetra kesulitan untuk mengetahui sebaran dan hubungan antar informasi. Peta taktual yang dikembangkan dalam ilmu kartografi, dimaksudkan untuk memenuhi kebutuhan tunanetra terhadap representasi fenomena geografis secara keruangan. Dengan Peta taktual, penderita tunanetra dapat membaca atau mengetahui sebaran dan hubungan antar fenomena geografi dengan meraba simbol-simbol yang ada pada peta. Untuk menyusun peta taktual yang baik, simbol, informasi tepi, dan reproduksi peta perlu dirancang sesuai kebutuhan dan kemampuan tunanetra sebagai pengguna. Sayangnya, hingga saat ini ketentuan-ketentuan tersebut belum terstandardisasi secara internasional. Bertitik tolak dari permasalahan tersebut, maka pada makalah ini dicoba menguraikan tentang disain simbol peta taktual yang diperoleh dari hasil modifikasi dari hasil pemetaan taktual kota oleh National Mapping Council of Australia; Publikasi Panduan Desain Gambar Taktual dari American Printing House; Penggunaan Variabel Taktual yang disusun oleh Vasconcellos; Spesifikasi Pemetaan Unsur Rupabumi dari BAKOSURTANAL; dan Penggunaan Variabel visual yang dikembangkan oleh Bertin Untuk Penyusunan Peta Kartografis. Hasil rancangan simbol peta taktual yang diperoleh dari modifikasi tersebut, selanjutnya diaplikasikan untuk menyusun peta taktual Kota Yogyakarta dengan media terpilih yaitu Swell Paper, dan selanjutnya dievaluasi dengan cara mewawancarai pengguna peta (tunanetra). Dua aspek yang dievaluasi, yakni (a) jenis peta taktual yang dibutuhkan oleh kaum tunanetra di Yogyakarta, dan (b) tingkat pengenalan kaum tunanetra terhadap variabel taktual.
\end{abstract}

Kata Kunci : Peta taktual

\section{PENDAHULUAN}

Pola pikir masyarakat yang tentang sumberdaya manusia yang berorientasi pada produktivitas, efektivitas, dan efisiensi di samping kekuatan dan mobilitas tinggi mengakibatkan penyandang cacat dipandang sebagai warga negara yang rendah dan lemah mobilitasnya, sehingga tidak tergolong sebagai SDM yang mempunyai arti penting bagi keberhasilan pembangunan (Coleridge, 1997). Salah satu penyandang cacat adalah tunanetra. Secara entimologi "tuna" = cacat dan "netra" = mata. Istilah tersebut menggambarkan keadaan penderita dengan kelainan penglihatan, baik bersifat berat (buta total) maupun ringan (low vision) (Pradopo, 1977).

Survei Kesehatan Indera Penglihatan dan Pendengaran tahun 1993 - 1996, angka kebutaan di Indonesia mencapai $1,5 \%$ dari jumlah penduduk, atau setara dengan 3 juta orang (Akhmadi, 2006). Tunanetra mengandalkan indera pendengaran dan perabaan untuk mengenali lingkungan dengan mengidentifikasi berbagai bentuk benda dan merekam beragam informasi (Pradopo, 1977). Mereka memerlukan sarana perolehan informasi yang dapat diterjemahkan dengan rabaan atau diperkuat dengan pendengaran. Termasuk di antaranya adalah kebutuhan akan informasi kebumian, yang diwujudkan dengan kehadiran peta taktual. Peta taktual secara konvensional (hard copy) dihasilkan dari representasi data spasial dalam simbol timbul pada suatu lembaran/permukaan (Fleming, 1986).

Ironisnya, peta taktual yang sangat bermanfaat untuk mendukung mobilitas harian maupun kepentingan pendidikan bagi tunanetra masih sukar diperoleh, termasuk di antaranya di kota Yogyakarta yang dinamis dan terkenal sebagai Kota Pelajar. Kebutuhan tersebut harus segera dipenuhi demi terciptanya pemerataan pembangunan sumber daya manusia dan kesempatan tunanetra sebagai pelaku pembangunan.

Memproduksi peta taktual yang efektif, dibutuhkan cara representasi data atau informasi dalam bentuk simbol dan tata letak 
yang mampu mengakomodasi kemampuan taktual tunanetra. Hanya dengan cara seperti itu, peta taktual yang dihasilkan sesuai dengan kebutuhan dan kapabilitas tunanetra. Uraian berikut akan menjelaskan tentang disain simbol pada peta taktual Kota Yogyakarta, dan menjelaskan tentang jenis peta yang dibutuhkan oleh tunanetra, serta menjelaskan tentang tingkat pemahaman tunanetra terhadap variabel taktual.

\section{PETA TAKTUAL}

Seperti halnya orang normal (orang awas), untuk mengenal fenomena geografis yang ada di sekitarnya, penderita tunanetra membutuhkan peta. Hanya saja, jenis peta yang dibutuhkan penderita tuna netra berbeda dengan orang normal. Orang awas dapat membaca peta dengan indera penglihatan, tetapi tuna netra memanfaatkan Tactile sensation untuk dapat membaca (termasuk membaca peta). Selanjutnya, peta yang dibaca dengan cara meraba informasi yang disajikan dalam bentuk simbol disebut peta taktual (Tactile Map). Karena peta taktual adalah salah satu sarana untuk membantu tuna netra dalam mengenali fenomena geografi, maka perlu dikembangkan. Peta taktual menghasilkan sarana rabaan (taktual) yang dapat diakses untuk mengetahui sebaran dan hubungan berbagai fenomena geografi dan efektif untuk mentransmisikan informasi keruangan kepada tunanetra, sehingga bermanfaat dalam mobilitas tanpa bantuan, maupun untuk peningkatan pemaknaan dari hubungan suatu fenomena yang masih abstrak. Oleh karena itu, menyediakan peta taktual yang efisien cara produksinya dan efektif untuk berkomunikasi sudah saatnya menjadi salah satu perhatian utama (Gruningen, 1979).

Tactile sensation adalah sensasi yang dirasakan ketika kulit mengalami kontak langsung dengan objek (seperti: getaran, denyutan, tekanan, temperatur, ukuran, bentuk, tekstur, arah, dan ketinggian), digunakan tunanetra untuk mengenali ruang (Griffin, 2001). Potensi tunanetra dalam tactile sensation ini melahirkan persepsi taktual yang diaktualisasikan menggunakan variabel taktual dalam pemetaan taktual untuk membedakan unsur yang diwakili pada masing-masing simbol pada peta. Tujuannya adalah untuk menimbulkan respon mental atai pikiran tertentu setelah diraba. Mengembangkan teori dari Bertin, Vasconcellos dan Griffin maka Dinar et.al, menemukan 6 macam variabel taktual yang cocok untuk memaksimalkan visualisasi ruang bagi tunanetra melalui media taktual, yaitu ukuran, nilai, bentuk, profil (adaptasi dari warna), tekstur, dan orientasi (Gambar 1.).

Untuk memproduksi peta taktual, perlu dirancang secara matang. Hal ini dikarenakan proses klasifikasi, abstraksi, simbolisasi, dan standardisasi dalam kaitannya dengan metode produksi agar sesuai dengan kebutuhan, serta agar dapat dibaca pada skala resolusi ujung jari perlu menjadi pertimbangan utama (Jacobson, 1999). Desain, produksi dan penggunaan peta taktual telah menarik perhatian peneliti di berbagai disiplin ilmu. Ditinjau dari bahan yang digunakan untuk membuat peta taktual dalam bentuk hard copy saja relatif banyak, seperti: menggunakan teknik raised inks, thermorfoming, vacuum forming, etching (mengetsa/mengikis), dan accretion (relief model) (Golledge et. al.,1997) dan teknik lain, yaitu embossing (Perkins, 2002). Peta taktual digital juga berkembang pesat untuk menyiasati rumitnya pembuatan peta taktual dalam bentuk hard copy, yaitu dengan penerapan GIS untuk mendukung mobilitas seperti halnya dilakukan oleh Jacobson dan Kitchin (1997), Clark (1997), 


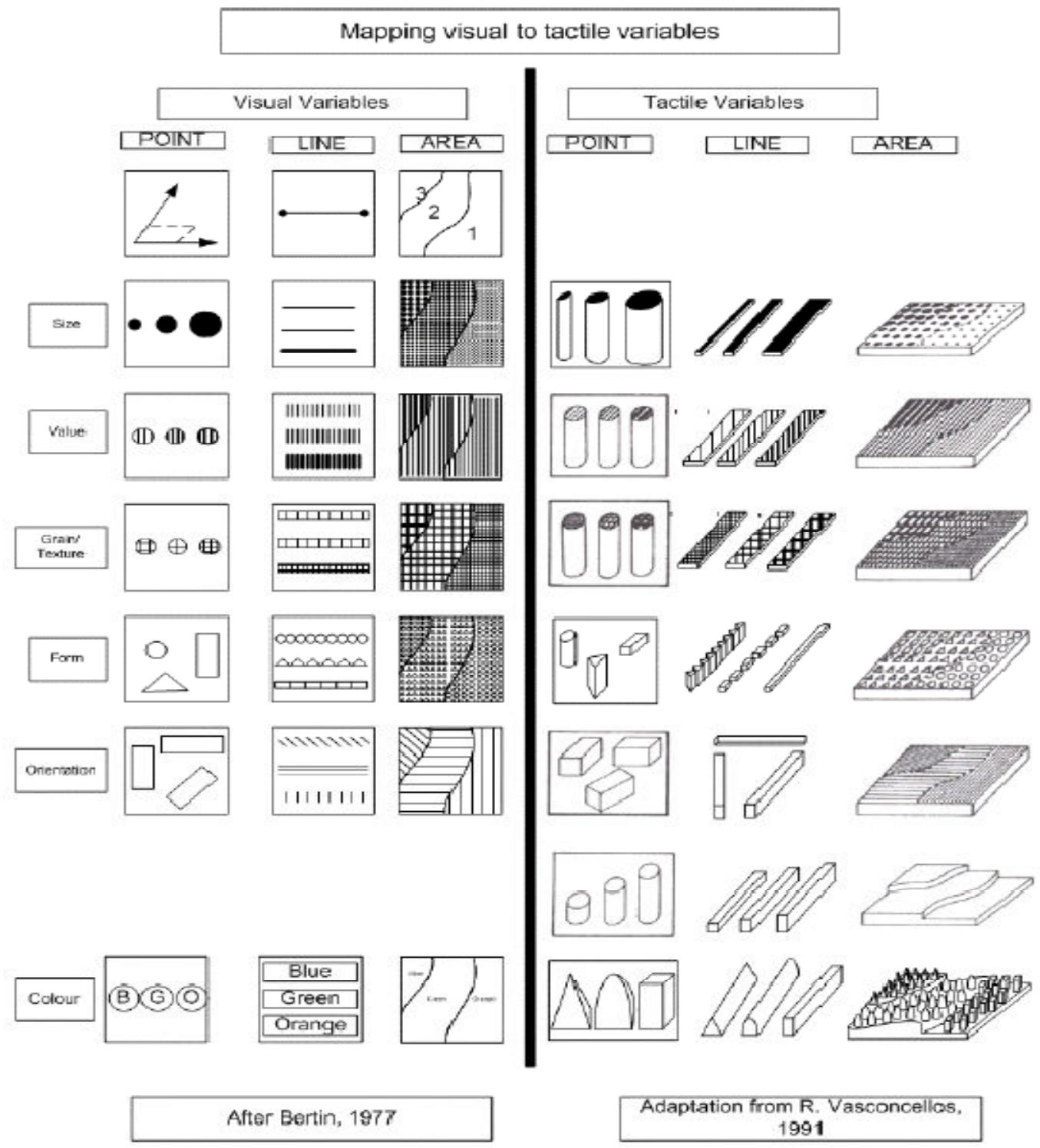

Sumber: Dinar et. al, t.t.

Gambar 1. Tactual Variable

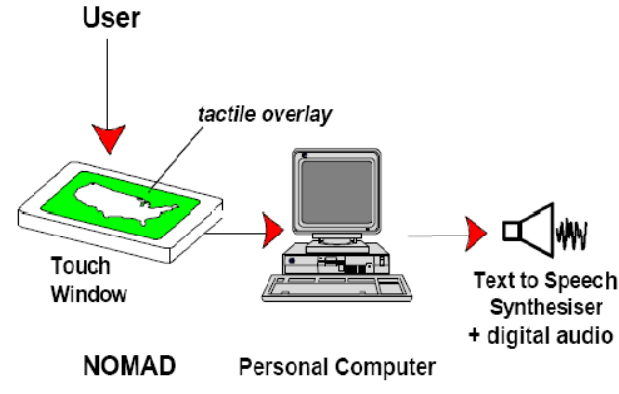

(a)

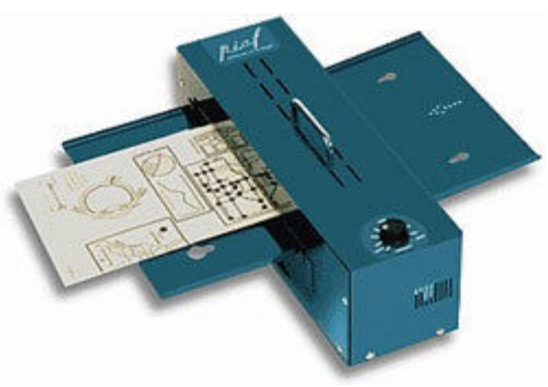

(b)

Sumber: $\underline{\text { Jacobson (1999) dan http://technologicalsolutions.info }}$

Gambar 2.a. Audio-tactile system NOMAD; 2.b Swell Paper dan Mesin Piaf 
Golledge et.al. (1991). Perkembangan lebih lanjut ialah dikombinasikannya GIS, peta digital, dan GPS-bases locating technology dengan multimedia, seperti NOMAD (Gambar 2.a.) dan TACIS (Perkins, 2002). Kehadiran swell paper, Minolta, dan microcapsule paper, menjadi terobosan dalam penerapan teknologi digital untuk memproduksi peta taktual dalam bentuk hard copy menjadi lebih mudah. Masuknya teknologi komputer dan software grafis dalam pembuatan hard copy peta taktual menjadikan proses edit, up date dan reproduksi ulang juga lebih praktis. Swell paper adalah sejenis kertas khusus yang memiliki kandungan microcapsule alkohol, sehingga merekah bila dipanaskan (periksa Gambar 2.b) (http://www.nctd.org.uk/MakingTG/ swell.asp).

Kunci yang harus dipegang dalam pemetaan taktual adalah untuk apa peta tersebut diproduksi. Peta tidak akan berarti apaapa jika desain peta tidak sesuai dengan siapa yang akan menggunakannya, dimana, dan kapan digunakan. Agar pemanfaatan peta taktual dapat optimal, partisipasi tunanetra dibutuhkan untuk proses desain dan produksi agar sesuai kebutuhan dan kemampuan penggunanya. Untuk kepentingan tersebut, diperlukan penggalian kemampuan yang dimiliki tunanetra pada level anak-anak dan dewasa sebagai pengguna peta (Ungar, 2000; Jasson, 2000 dalam Perkins, 2002).

\section{TAHAPAN-TAHAPAN PRODUKSI PETA TAKTUAL KOTA YOGYAKARTA}

Produksi peta taktual Kota Yogyakarta melalui beberapa tahap, diawali dengan:

(a) Pemilihan informasi rupabumi yang dihimpun dari wawancara dengan tuna netra, dengan pertimbangan rambu-rambu pada PP No. 10 Tahun 2000, tentang Tingkat Ketelitian Peta untuk Penataan Ruang Wilayah, dan referensi hasil penelitian dari Megan Lawrence dan Xiangkui Xao terhadap 140 tunanetra di Oregon, mengenai peringkat kepentingan simbol untuk dipetakan dalam peta taktual. Kegiatan ini dilanjutkan dengan penentuan skala peta terpilih, dengan tingkat kedetilan informasi yang diinginkan sesuai standard atau baku pemetaan kota, yaitu antara $1: 10.000-1: 25000$ bagi peta yang ditujukan untuk kepentingan orientasi, atau Ibih dari 1:25000 - 1:50000 untuk peta referensi.

(b) Desain simbol taktual dilakukan sesuai prinsip variabel taktual, yang mengacu kepada penyederhanaan atau perbesaran simbol standar peta Rupabumi Indonesia dari BAKOSURTANAL (2003), desain-desain dan aturan simbolisasi yang dikeluarkan oleh National Mapping Council of Australia (1985), panduan desain gambar taktual yang di rilis dari American Printing House for The Blind (1997), dan beberapa penelitian terdahulu yang berkaitan dengan desain simbol peta taktual. Simbol dibuat sesederhana mungkin namun tetap mampu mewakili perbedaan informasi yang diharapkan dapat dengan mudah dikenali pengguna peta.

Beberapa pertimbangan yang digunakan dalam desain simbol taktual antara lain:

\section{Ukuran simbol}

a. Edman (1992) dalam McCullum (2005) menyatakan bahwa diameter atau panjang sisi $5 \mathrm{~mm}$ adalah ukuran simbol terkecil yang dapat digunakan oleh tunantera untuk membedakan bentuk simbol titik.

b. National Mapping of Australia (1985) menyebutkan bahwa jika terdapat paling tidak 3 tingkatan garis dalam peta maka pengkelasan ukuran dapat dilakukan seperti pada Gambar 3.

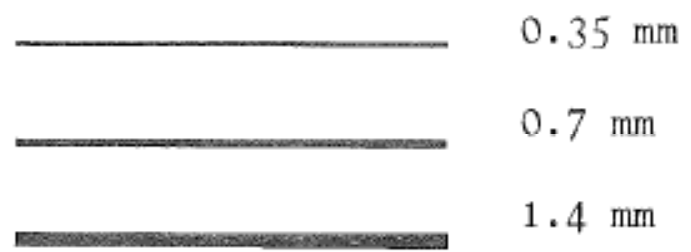

Sumber: National Mapping Council of Australia (1985)

\section{Gambar 3. Pengkelasan Ukuran pada Garis}

Berdasarkan pertimbangan bahwa ukuran terkecil yang sudah biasa dikenali atau diraba tuna netra adalah 1 cell braille, yaitu setengah bola berdiameter $=1 \mathrm{~mm}$ dengan tinggi $=0.5$ $\mathrm{mm}$, maka ditetapkan bahwa lebar garis tunggal terkecil adalah $0.5 \mathrm{~mm}$ untuk lebih menonjolkan kenampakan garis, dan dengan pertimbangan banyaknya fasilitas/objek yang terletak di kelas jalan lokal di Kota Yogyakarta. Simbol area ditunjukkan dengan keberadaan pola atau tekstur (Gambar 4). Simbol di atas menunjukkan area yang ditandai dengan garis setebal 0.35 $\mathrm{mm}$. Atau pada kondisi tertentu dapat digunakan lebar garis $0.7 \mathrm{~mm}$ dengan melakukan pengurangan jarak antar garis menjadi $3 \mathrm{~mm}$. 

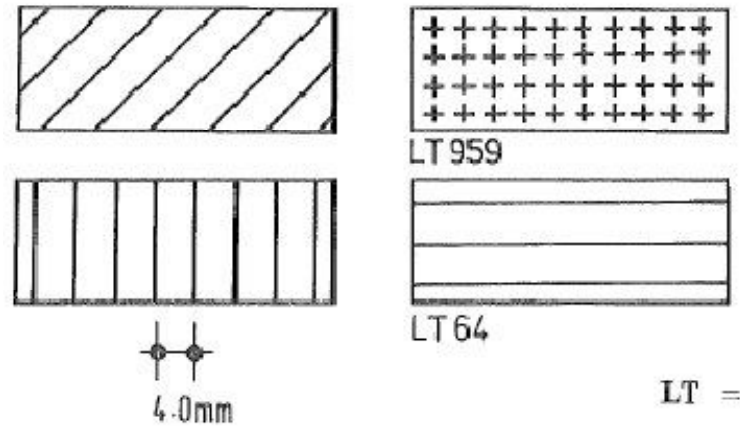

LT 959

Sumber: National Mapping Council of Australia (1985)

Gambar 4. Simbol Area

\section{Jarak antar simbol-simbol dan braille}

a. Antara titik, garis, dan braille (label/toponimi) harus saling terpisahkan minimal $3 \mathrm{~mm}$, periksa Gambar 5 .

Knight (2010) yang memiliki profesi dalam pemetaan taktual pada swell paper, menyatakan bahwa jarak antar simbol, dan simbol dengan braille dapat ditoleransi hingga jarak $2 \times 2$ dot braille (1 $\mathrm{mm})$, karena tunanetra telah terbiasa untuk mendetekti dot yang menyusun huruf braille.

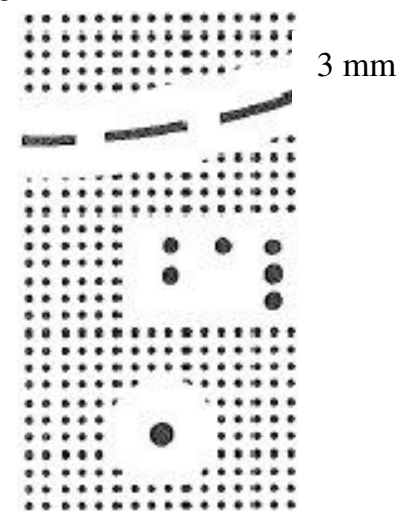

Sumber: National Mapping Council of Australia (1985)

\section{Gambar 5. Jarak antar Simbol dan} Braille

\section{Ketinggian simbol}

a. Ketinggian minimal untuk masing-masing simbol (titik, garis, area) $=0.5 \mathrm{~mm}$.

\section{Jarak antar simbol-simbol dan braille}

a. Inisial braille atau label diberikan untuk menerangkan symbol-simbol tertentu sedapat mungkin, terdiri atas dua cell braille.

b. Pada kajian kumpulan peta, skala dan orientasi tidak harus diberikan pada seluruh lembar peta apabila dikawatirkan merumitkan data. Informasi koordinat diberikan sesederhana mungkin, tidak merupakan informasi yang diutamakan.

c. Judul, petunjuk membaca peta, dan legenda diletakkan sebelum gambar peta. Jika tidak cukup, dapat diletakkan pada lembar sebelumnya.

d. Overlap $\pm 2 \mathrm{~cm}$ untuk menjaga agar sensasi taktual dari ujung jari dapat berjalan baik.

Dalam penyusunan peta taktual Kota Yogyakarta, data spasial digital batas administrasi, jalan, dan sungai diperoleh dari digitisasi menggunakan perangkat pengolahan data spasial, seperti ArcGIS 9x, dari peta RBI skala 1:25000 liputan Kota Yogyakarta dan Peta Kota Yogyakarta skala 1:9000 untuk menambahkan informasi lain yang dibutuhkan. Dilakukan generalisasi sesuai kebutuhan dengan mengacu pada panduan dalam Spesifikasi Pemetaan Rupabumi dari BAKOSRTANAL (2003) agar peta dapat terbaca oleh tuna netra. Penambahan informasi titik, label, dan layout dilakukan pada perangkat lunak desain grafis, seperti CorelDRAW X4.

\section{c. Tahap produksi hard copy}

Untuk mencetak peta taktual Kota Yogyakarta, dipilih swell paper berukuran A3 (dengan proses fotocopi akan memberikan hasil taktual yang lebih maksimal setelah dipanaskan) dan memanaskannya dengan mesin pemanas (PIAF) untuk menghasilkan Peta Taktual Kota Yogyakarta. Dipilihnya jenis media swell paper, didasarkan pada penelitian yang telah dilakukan oleh Jehoel et.al (2005) yang menunjukkan bahwa swell paper adalah media yang efektif dalam membuat hard copy peta taktual, seperti diilustrasikan pada Gambar 6 berikut. 


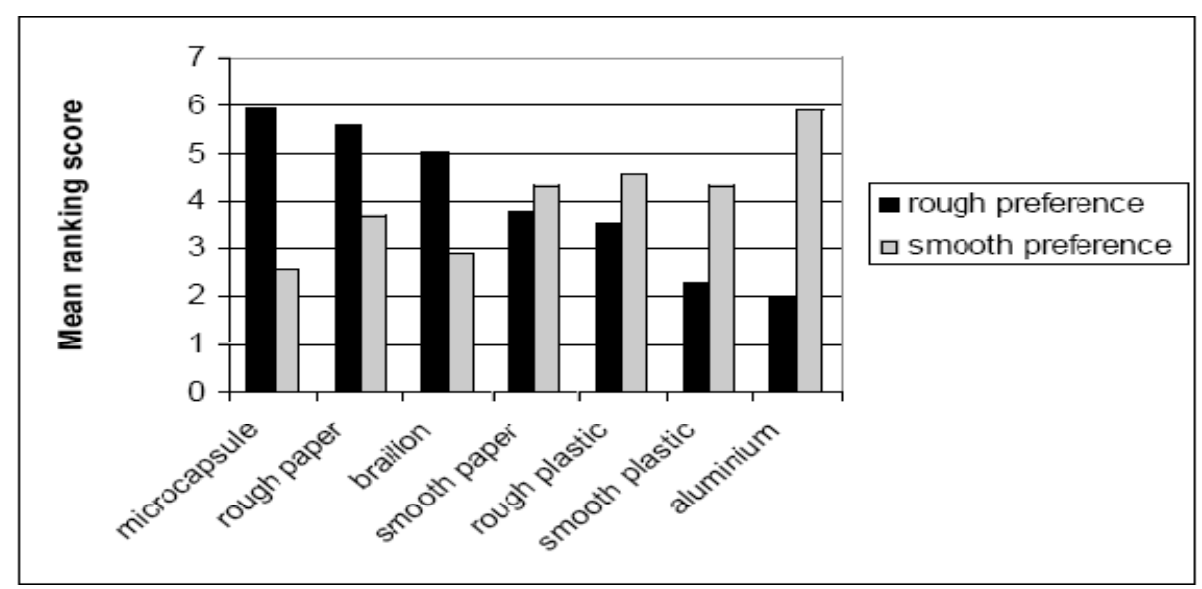

Sumber: Joehoel et. al (2005)

Gambar 6. Peringkat Rata-Rata Pemilihan Substrat

\section{STANDARDISASI PETA TAKTUAL DI INDONESIA (RINTISAN)}

Peta yang baik dapat dikatakan sebagai peta yang benar dan efektif. Benar dalam artian merepresentasikan fenomena geografis secara tepat sesuai kaidah kartografis, dan efektif karena dapat memenuhi kebutuhan pengguna peta secara menyeluruh namun tidak berlebihan. Dengan demikian, komunikasi yang dilakukan melalui jalur komunikasi kartografis dapat berjalan maksimal. Adanya standarisasi peta taktual akan menjamin komunikasi kartografis yang efektif, dan kebutuhan tunanetra terhadap ketersediaan sumber data untuk pengamatan atau analisis data kebumian dapat terpenuhi.

Berdasarkan hasil penyusunan peta taktual Kota Yogyakarta yang disusun oleh lka Noor Muslihah bersama Noorhadi Rahardjo (2010), setidaknya dapat digunakan sebagai pedoman untuk menyusun standardisasi peta taktual di Indonesia, walaupun bersifat rintisan. Dua aspek penting yang dapat diperoleh dari hasil penyusunan peta taktual tersebut, yakni (1) jenis peta taktual yang dibutuhkan oleh tuna netra, dan (2) spesifikasi simbol pada peta taktual.

\section{a. Jenis Kebutuhan Peta Taktual}

Untuk mengetahui jenis kebutuhan peta taktual yang dibutuhkan oleh penderita tuna netra, telah diambil sampel (60 responden) yang terdiri dari dua kelompok, yakni kelompok tuna netra usia sekolah dan kelompok tuna netra yang sudah bekerja masing-masing 30 responden. Pembagian kelompok tersebut dimaksudkan untuk menjaring kemungkinan adanya perbedaan dalam pemilihan jenis peta dan informasi yang dibutuhkan. Berdasarkan hasil analisis, terbukti bahwa kedua kelompok tersebut memiliki kepentingan yang sama dalam mengakses informasi kebumian melalui peta taktual, yaitu untuk mendapatkan pemahaman orietasi kewilayahan yang diperoleh dari pengenalan posisi objek terhadap objek lain di wilayah Kota Yogyakarta. Hasil dari analisis kebutuhan peta taktual, dapat diperiksa pada Gambar 7.

\section{(i) Peta Administrasi Kota Yogyakarta}

Peta Administrasi Kota Yogyakarta adalah sebuah peta (dalam hal ini adalah peta taktual administrasi) yang dirancang untuk menampilkan informasi pembagian daerah administrasi mulai dari tingkat Kotamadya hingga kelurahan dalam satu kesatuan utuh. Dalam peta taktual, peta ini termasuk jenis peta referensi kewilayahan. Maksud pembuatan peta ini adalah untuk memberikan pemahaman kepada pengguna peta (tuna netra) mengenai gambaran wilayah secara umum. 


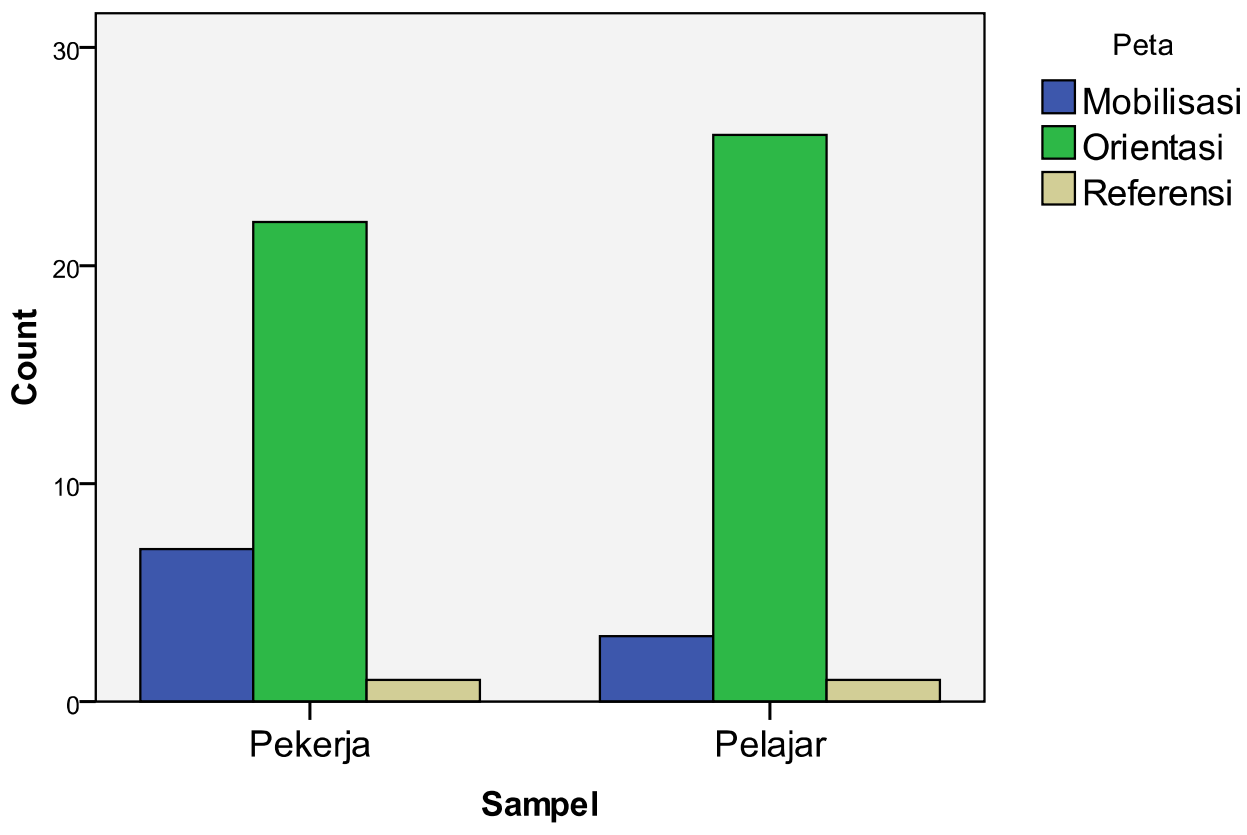

Gambar 7. Perbandingan kebutuhan jenis peta taktual pada dua sampel

\section{(ii). Peta Orientasi Kota Yogyakarta}

Peta orientasi Kota Yogyakarta merupakan sebuah peta yang menggambarkan objek rupabumi terpilih, agar pengguna peta (tuna netra) dapat mengetahui jenis objek dan posisi atau letak objek tersebut secara relatif. Peta tersebut diharapkan, dapat membantu meningkatkan pemahaman keruangan kepada tuna netra terhadap objek-objek terpilih, dan sekaligus dapat digunakan sebagai alat bantu untuk perencanaan perjalanan.

Banyaknya informasi tentang jenis objek di permukaan bumi di Kota Yogyakarta yang diinginkan tuna netra untuk diketahui posisinya, mengakibatkan peta taktual yang dibuat harus mempunyai skala relatif besar. Untuk membuat peta taktual dengan skala besar diperlukan media atau substrat yang semakin banyak, karena ketersediaan swell paper maksimal berukuran A3. Sebagai konsekuensi, peta yang berskala besar tersebut harus dibuat secara mozaik, atau membagi liputan peta ke dalam beberapa lembar yang terpisah, seperti yang disajikan pada Lampiran 2.

\section{b. Spesifikasi Simbol Taktual untuk Pemetaan Kota}

Kemampuan tuna netra dalam membaca peta taktual, dipengaruhi oleh tingkat kepekaan indera peraba khususnya ujung jari. Tingkat kepekaan indera peraba lebih ditentukan oleh pengalaman masing-masing individu tuna netra dalam mengeksplorasi kemampuan rabaannya. Dari hasil penelitian tentang tingkat pengenalan variabel taktual dengan menggunakan peta taktual orientasi Kota Yogyakarta terhadap 60 orang tuna netra yang digunakan sebagai responden, menunjukkan bahwa pada dasarnya semua variabel taktual dapat dipahami. Namun demikian bila dilakukan pengelompokan, terdapat tiga variabel taktual, masing-masing: bentuk, tekstur, dan ukuran adalah variabel taktual yang sangat mudah dikenali; sedangkan variabel taktual orientasi, nilai, dan profil relatif lebih sulit dikenali oleh tuna netra. Berdasarkan hasil penelitian tersebut, dapat disimpulkan bahwa : (1) semua variabel taktual dapat dikembangkan sebagai variabel untuk membuat simbol pada peta taktual; dan (2) variabel taktual bentuk, tekstur, dan ukuran merupakan variabel-variabel yang memiliki potensi tinggi untuk dikembangkan dalam desain simbol kartografis pada pemetaan taktual.

Untuk mengetahui hasil penelitian terhadap tingkat pengenalan variabel taktual oleh tuna netra, dapat diamati pada Gambar 8 berikut. 


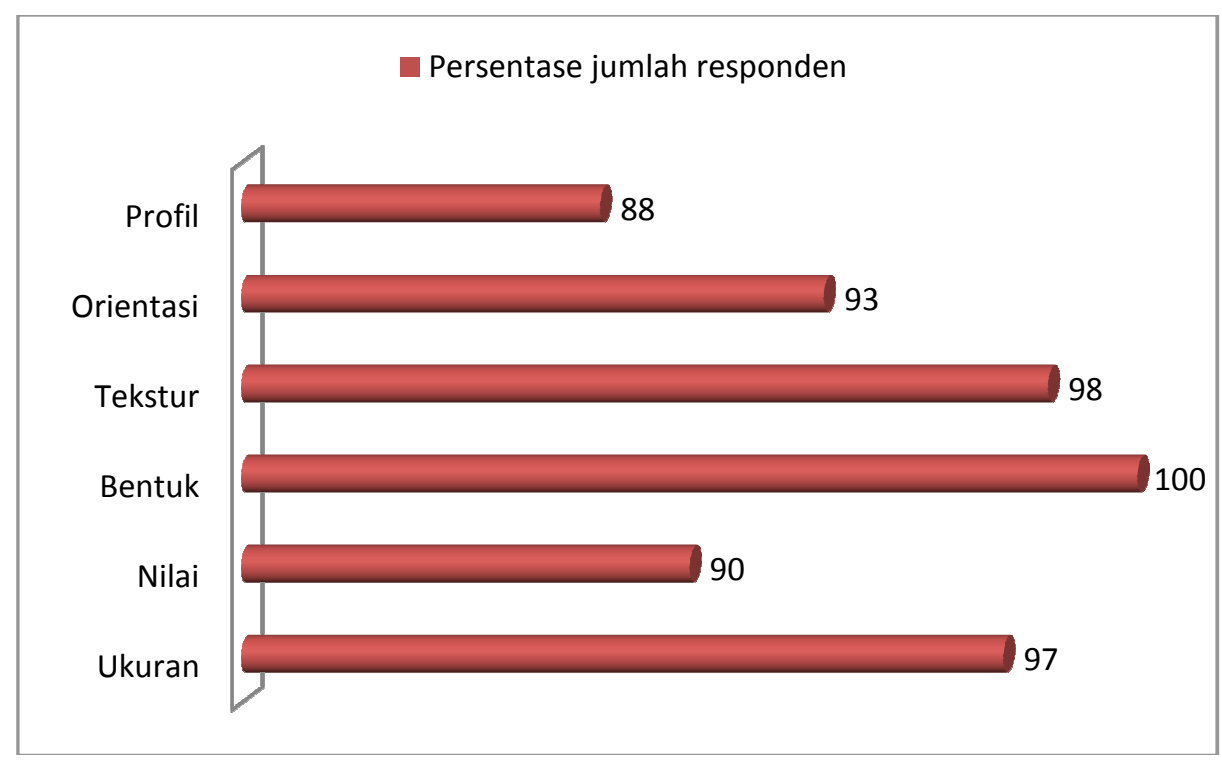

\section{Sumber : Survei tanggal 10 - 12 Oktober 2009 di Yogyakarta \\ Gambar 8. Grafik perbandingan tingkat pengenalan responden terhadap variabel taktual}

Seperti disebutkan pada uraian sebelumnya, bahwa tuna netra mempunyai keterbatasan dalam memahami semua objek di permukaan bumi. Karena keterbatasan tersebut, maka tuna netra mempunyai ketertarikan sendiri terhadap unsur-unsur yang disajikan pada peta taktual. Pada Tabel 1 disajikan hasil tabulasi terhadap objek-objek yang dibutuhkan oleh tuna netra untuk disajikan pada peta orientasi, yang diperoleh dari hasil penelitian terhadap 60

Tabel 1. Jumlah Keterpilihan Informasi untuk Peta Orientasi

\begin{tabular}{|c|l|c|}
\hline No & \multicolumn{1}{|c|}{ Objek } & Jumlah \\
\hline 1 & $\begin{array}{l}\text { Gedung, bangunan, dan } \\
\text { fasilitas } \\
\text { melingkupinya }\end{array}$ & 60 \\
\hline 2 & Perhubungan yang & 60 \\
\hline \multicolumn{2}{|c|}{ Berdasarkan referensi dari National } \\
\hline
\end{tabular}
Mapping Council of Australia; Publikasi Panduan Desain Gambar Taktual dari American Printing House; Penggunaan Variabel Taktual yang disusun oleh Vasconcellos; Spesifikasi Pemetaan Unsur Rupabumi dari BAKOSURTANAL; dan Penggunaan Variabel Visual yang dikembangkan oleh Bertin Untuk Penyusunan Peta Kartografis; Spesifikasi Pemetaan Rupabumi BAKOSURTANAL; dan hasil penelitian yang dilakukan terhadap tuna netra di Kota Yogyakarta, maka dapat disusun desain simbol peta taktual. Diharapkan, hasil responden (tuna netra). Ada tiga objek yang diinginkan oleh para tuna netra untuk disajikan pada peta orientasi taktual. Ketiga objek tersebut adalah (a) gedung, bangunan, dan fasilitas-fasilitas yang melingkupinya; (b) perhubungan; dan (c) toponimi atau nama-nama geografi. Berdasarkan hasil penelitian ini, maka ketiga jenis objek itulah yang perlu diutamakan untuk disajikan pada peta taktual.

\begin{tabular}{|c|l|c|}
\hline 3 & Relief dan titik control & 2 \\
\hline 4 & Area terbuka & 13 \\
\hline 5 & Batas administrasi & 18 \\
\hline 6 & Perairan & 26 \\
\hline 7 & Label/toponimi & 60 \\
\hline
\end{tabular}

2013.

Sumber : Hasil Analisis Data Primer

rancangan simbol taktual ini dapat digunakan sebagai rancangan standardisasi peta taktual di Indonesia, yang hingga saat ini belum ada standart baku. Hasil desain simbol taktual tersebut dapat disajikan pada Lampiran 3.

\section{KESIMPULAN}

Peta taktual dibuat dengan tujuan untuk lebih memberdayakan tuna netra demi terciptanya pemerataan pembangunan sumberdaya manusia, dan memberi kesempatan tuna netra sebagai pelaku 
pembangunan. Oleh sebab itu, keberadaan peta taktual perlu dipikirkan dan dikembangkan.

Jenis peta taktual yang dibuat dengan tujuan memberikan orientasi kewilayahan adalah jenis peta taktual yang dibutuhkan oleh tunanetra (khususnya tuna netra di Kota Yogyakarta). Peta tersebut sebaiknya dibuat pada skala besar, karena unsur rupabumi yang dibutuhkan oleh tuna netra relatif banyak, sedangkan sarana membacanya menggunakan ujung jari.

Banyaknya generalisasi yang dilakukan pada penyusunan peta taktual, seperti : penyederhanaan, perbesaran, pergeseran, dan pemilihan yang dilakukan menjadikan informasi posisi absolut pada peta tersebut tidak akurat. Dengan demikian, informasi yang dihasilkan dititik-beratkan pada informasi relatif yang diperoleh dari kedudukan suatu objek terhadap objek lain di sekitarnya. Kondisi ini tidak menjadi permasalahan sejauh peta taktual difungsikan sebagai petunjuk orientasi, saja seperti harapan yang disampaikan tunanetra selama proses wawancara dan diskusi yang telah dilaksanakan dibagain awal dari penelitian ini.

Keterbatasan jumlah dan luasan swell paper mengakibatkan peta taktual yang dibuat pada skala besar tidak dapat disajikan dalam satu lembar, tetapi harus dibuat secara mozaik atau membagi liputan peta ke dalam beberapa lesmbar yang terpisah. Kondisi ini menjadikan peta taktual terasa kurang praktis penggunaannya.

Sebagai tindak lanjut dari penelitian ini, sebaiknya dibuat buku panduan penggunaan peta taktual disamping melakukan kegiatan pelatihan membaca peta untuk tunanetra agar tunanetra agar peta taktual dapat digunakan semudah dan seefektif mungkin. Penelitian mengenai desain dan produksi peta taktual secara kartografis di Indonesia harus terus dikembangkan, karena memiliki potensi nilai guna dan ekonomi yang tinggi.

\section{DAFTAR PUSTAKA}

Akhmadi, Irfan Mulia. 2006. Public Sign Fasilitas Umum Transjakarta untuk Kaum Tunanetra. Skripsi. Fakultas Seni Rupa. Institut Kesenian Jakarta.

Amick, N., Corcoran, J., dan staf APH. 1997. Guidelines for Design of Tactile Graphics. American Printing House for the Blind. Diambil tanggal 5 Agustus 2009, dari http://www.aph.org/ edresearch/guides.htm.
Clark, J \& Clark, D. 1994. Creating Tactile Maps for The Blind Using a GIS. Diambil tanggal 2 Februari 2010, dari http://trsnew.jpl.nasa.gov/dspace/bitstrean/2014/ 32438/1/94-0177.pdf.

Coleridge, Peter. 1997. Pembebasan dan Pembangunan. Pustaka Pelajar. Yogyakarta.

Dinar, S., Rowell, J., \& McCullum, D. t.t . The Uniqueness of Symbol Profile as a Design Variable in Tactile Cartography. Department of Geography. Anglia Polytechnic University. United Kingdom.

Fleming, L Joan. 1986. Scale Variation in Tactual Maps: Implications for Improved Mobility. Simon Fraser University. Vancouver. Diambil tanggal 29 Januari 2010, dari http://ir.lib.sfu.ca/bitstream/1892/7673/1/b16 551977.pdf.

Golledge, Reginald G., Loomis, Jack M., \& Klatzky, Roberta L. 1997. A New Direction for Applied Geography. The University of California Transportation Center. University of California-Berkeley. Applied Geographical Studies Vol 1, no 3, pp I51168 UCTC No. 472. Diambil tanggal 31 Juni 2009, dari ProQuest.

Griffin, Amy L. 2001. Feeling It Out: The Use of Haptic Visualization for Exploratory Geographic Analysis. Cartographic Perspectives. Number 39 (Spring 2001) pp. 12-29.

Gruningen, V Susan. 1979. Tactual orientation/Mobility Maps Production and Testing. The Ohio State University. Battelle Laboratories. Columbus. Ohio.

Jacobson, R Daniel. t.t-b . The Future of Tactile Cartofraphy: From Static Raised Lines to Multimodal Dynamic Portable Computer Interfaces. Departemen Geografi. University of Calgary. Diambil tanggal 31 Juli 2009 dari http://www.immerse. ucalgary.ca

Jehoel, S., Ungar, S., McCallum, D., \& Rowell. 2005. An Evaluation of Substrates for Tactile Maps and Diagrams: Scanning Speed and User Preferences. Journal of Visual Impairment and Blindness, vol: 99, hal: 85-95. 
Lawrence, M. \& Xao, X. t.t. Tactile Mapping Sofware for Blind and Low Vision Science Education. Diambil tanggal 18 Januari 2010, dari http://ix.cs.ueregon.edu/ ficas/project/JAM0 7.pdf.

McCallum, D., Ahmed, K., Jehoel, S, Dinar, S., \& Sheldon, D. 2005. The Design and Manufacture of Tactile Maps Using an Inject Process. Journal of Engginering Design. Vol. 16 . No. 6. Desember 2005, hal. 525 - 544. Diambil pada 31 Juli 2009, dari Proquest.

National Mapping Council of Australia. 1985. A National Specification for Tactual and Low Vision Town Maps. Canberra. Australia.

Ogrosky, Charles E. t.t. Current Research in Tactual Cartography. Rutgers University.

Perkins, Chris. 2002b. Tactile Mapping Quality: The Manchester Experience. School of Geography. University of Manchaster. Diambil tanggal 29 Januari 2010 dari http://www.mangeogsoc.org.uk/pdfs/perkins .pdf.

Pradopo, Soekini, dkk. 1977. Pendidikan AnakAnak Tuna Netra. Depertemen Pendidikan dan Kebudayaan. Jakarta.

Zhao, Z., Haiyan, L., Shaomei, L., \& Jihua, X. t.t Modern Cartographic Language. Departement of Cartography. Institute of Surveying and Mapping. Zhengzhou. China. Diambil tanggal 31 Juli 2010, dari Proquest. 